
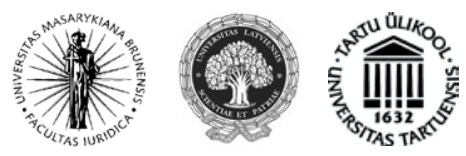

ISSN 1392-6195 (print) ISSN 2029-2058 (online) JURISPRUDENCIJA

\title{
NAUJO INDIVIDUALIŲ DARBO GINČŲ SPRENDIMO MODELIO VEIKIMO YPATUMAI
}

\author{
Justinas Usonis \\ Mykolo Romerio universiteto Teisès fakulteto \\ Verslo teisès katedra \\ Ateities g. 20, LT-08303 Vilnius, Lietuva
}

Telefonas (+370 5) 2714633

Elektroninis paštas justinas@usonis.lt

\section{Asta Filimonenkova}

Mykolo Romerio universiteto Teisès fakulteto

Darbo ir socialinio aprūpinimo programos magistrantè

Ateities g. 20, LT-08303 Vilnius, Lietuva

Telefonas (+370 6) 7138002

Elektroninis paštas asta.filimone@gmail.com

Pateikta 2013 m. lapkričio 23 d., parengta spausdinti 2014 m. sausio 2 d.

doi:10.13165/JUR-13-20-4-06

\section{Ivadas}

Nuo 2013 m. sausio 1 d. ịsigaliojusi nauja Lietuvos Respublikos darbo kodekso (toliau - DK) XIX skyriaus redakcija įtvirtino naują individualių darbo ginčų sprendimo mechanizmą. Iki tol DK XIX skyriaus trūkumai ne kartą buvo analizuoti ir aptariami mokslinėse diskusijose vieningai sutariant ${ }^{1}$, jog darbo ginčų institutas reikalauja dau-

1 Atskirais aspektais yra pasisakę Lietuvos mokslininkai G. Bužinskas, G. Dambrauskienė, I. Mačernytė-Panomariovienè, T. Davulis, V. Mačiulaitis, J. Usonis, T. Bagdanskis, J. Judickienė, D. Petrylaitè ir I. Blažienè. 
giau dèmesio iš teisékūros subjektų, o galiojanti individualių darbo ginčų nagrinejjimo tvarka iš esmès turi būti keistina siekiant efektyvesnio darbuotojų interesų gynimo. Individualūs darbo ginčai (toliau - darbo ginčai) darbdavio sudaromose komisijose ne visuomet būdavo nagrinèjami objektyviai arba išvis nebūdavo nagrinèjami, taip ignoruojant įstatymų leidejo imperatyvų reikalavimą spręsti kylančius nesutarimus tarpusavyje. Naujaja tvarka nuo 2013 m. sausio 1 d. ịstatymų leidèjas pavedė darbo ginčus spręsti Lietuvos Respublikos valstybinès darbo inspekcijos prie Socialinės apsaugos ir darbo ministerijos (toliau - VDI) sudaromose darbo ginčų komisijose, kuriose darbo ginčai sprendžiami pasitelkiant i pagalbą socialinius partnerius. Tokia reforma buvo siekiama paskatinti darbuotojus aktyviau ginti savo pažeistas teises, taip pat palengvinti paties darbdavio naštą sudaryti kilusio darbo ginčo nagrinèjimo komisiją darbovietėje bei, vadovaujantis darbo teisinių santykių subjektų lygiateisiškumo principu, įtvirtinti galimybę pačiam darbdaviui kreiptis ị darbo ginčų komisiją dèl darbuotojo veiksmų. Naujoji darbo ginčų nagrinejjimo tvarka turètų gerokai supaprastinti nesutarimų tarp darbuotojų ir darbdavių sprendimų mechanizmą, siekiant kiek įmanoma objektyvesnių ir efektyvesnių sprendimų, supaprastintų darbo ginčo nagrinèjimo procedūrų. Straipsnyje pateikiama darbo ginčų komisijų (toliau - DGK) kalendorinių metų darbo apžvalga, aktualiausios problemos, tendencijos bei perspektyvos lyginant užsienio šalių darbo ginčų sprendimo praktiką bei teisès aktus, kuriais DGK vadovaujasi savo veikloje.

\section{Individualių darbo ginčų nagrinëjimas iki $2013 \mathrm{~m}$. sausio $1 \mathrm{~d}$.}

Darbo ginčui, kaip savarankiškam darbo teisès institutui, iki 2013 m. sausio 1 d. nagrinèti buvo taikoma dvipakopè sistema, kai prieš kreipiantis ị teismą darbo ginčai turèjo būti nagrinèjami darbdavio sudaromoje darbo ginčų nagrinèjimo komisijoje, kuri buvo privalomas pirminis organas, nagrinejantis darbo ginčus ${ }^{2}$. Tiesiogiai teismuose darbo ginčai buvo nagrinejjami, kai komisijoje šalys nepasiekè bendro konsensuso, kai komisija apskritai nebuvo sudaryta arba darbo ginčas komisijoje nebuvo išspręstas per ịstatymo nustatytus terminus, taip pat ginčai, kilę dèl darbo sutarties, dèl atleidimo iš darbo formuluotès pakeitimo, tarp profesinių sajungų ar kitų darbuotojų atstovų ir darbdavio dèl ịstatymuose ar sutartyje nustatytų pareigų ir prievolių nevykdymo, pagal profesinių sajungų ieškinius, kai darbdavys laiku neišnagrinejja ar nepatenkina profesinės sajungos reikalavimo panaikinti darbdavio sprendimus, kurie pažeide įstatymų nustatytas darbo, ekonomines ir socialines profesinių sajungų narių teises, kai darbo santykiai tarp darbdavio ir darbuotojo buvo nutrūkę ir kitais ịstatymų nustatytais atvejais ${ }^{3}$. Kaip matyti, didžioji dalis darbo ginčų buvo nagrinejami bendrosios kompetencijos teismuose, kurie buvo perkrauti darbo bylomis, dèl ko procesas būdavo ilgas, sudètingas ir brangus. Dèl to ne visi darbuotojai turédavo galimybę kreiptis ị teismą, kas reiškia, jog dalis darbo ginčų apskritai nebuvo sprendžiami, taip eliminuojant darbuotojų galimybę apginti savo 
galimai pažeistas teises. Remiantis statistiniais duomenimis, 2011 metais 1816 darbo bylų buvo nagrinėjamos iki 6 ménesių, 438 bylos nuo 6 iki 12 mėnesių, 193 bylos buvo nagrinėjamos ilgiau nei 12 mènesių. 2012 metais 2107 darbo bylų buvo nagrinėjamos iki 6 mėnesių, 261 bylos nuo 6 iki 12 mėnesių, 94 bylos buvo nagrinèjamos ilgiau nei 12 mènesių ${ }^{4}$. Akivaizdu, jog toks darbo ginčų sprendimo būdas nebuvo nei greitas, nei efektyvus, tad darant reformą buvo analizuojama taip pat ir kitų šalių individualių darbo ginčų nagrinèjimo praktika.

\section{Darbo ginčų sprendimas Europos Sajungos valstybėse}

G. Bužinsko nuomone, naujajam individualių darbo ginčų nagrinëjimo modeliui Europos Sajungos teisès standartu įtaka yra minimali. Tokia išvada yra pagrịsta tuo, kad darbo ginčų komisijos, kaip ikiteisminès privalomos individualių darbo ginčų nagrinejjimo institucijos „fenomenas“ yra žinomas tik posovietinès erdvès šalims ${ }^{5}$. Kaip pavyzdį G. Bužinskas pateikia Airiją, pagal kurios teisę, ,tais atvejais, kai darbdavys su darbuotojais nesusitaria ir tarp jų kyla ginčas, galima kreiptis į darbo santykių komisiją. Tam, kad ginčas darbo santykių komisijoje būtų išnagrinètas greitai ir efektyviai, ịstatymas numato galimybę pasitelkti nepriklausomą mediatorių arba tarpininką. Jeigu ir jų dalyvavimas nepadeda išspręsti konflikto, tuomet kreipiamasi ị teismą. Tačiau ir i šią tvarką jau reikia žvelgti iš istorinès retrospektyvos, kadangi 2012 metais Airijos Respublikoje atlikta ịstatymų reforma, kurios tikslas - sukurti tokią darbo ginčų nagrinejjimo tvarką, kuri užtikrins „svorio centro“ perkėlimą iš darbo santykių komisijos i teismą. Taigi, galima konstatuoti, kad darbo ginčų komisijos istoriškai susiformavo toje terpèje, kuriai būdingas perdètas institucionalizavimas ir formalizavimas “6. Kitose užsienio šalyse darbo ginčai nagrinėjami ịvairiai: teismuose arba administracinėse institucijose. Europos šalyse tokie ginčai nagrinèjami arba bendruosiuose civiliniuose teismuose (Italijoje, Olandijoje), arba - daugumoje šalių - specializuotuose darbo teismuose (Didžiojoje Britanijoje, Vokietijoje, Austrijoje, Prancūzijoje, Belgijoje, Švedijoje, Šveicarijoje (kai kuriuose kantonuose), Norvegijoje, Suomijoje, Izraelyje. Specializuoti darbo teismai yra ir Kanadoje (Kvebeko provincijoje), Naujojoje Zelandijoje, Japonijoje. JAV, Japonijoje ir Kanadoje (federaliniu lygiu ir angliškai kalbančiose provincijose) veikia administracinės institucijos, atliekančios atskirų teismų funkcijas. Specializuoti darbo teismai paprastai daugelyje šalių ịtraukiami ị bendrą teismų institucinę sistemą, ir tik keliose šalyse - Airijoje, Austrijoje, Vokietijoje ir Izraelyje - darbo teismai turi visišką autonomiją ir plačią jurisdikciją. Specializuoti šioje sistemoje yra ne tik pirmosios instancijos, bet ir apeliacinès bei revizinès instancijų teismai ${ }^{7}$.

4 Nacionalinè teismų administracija [interaktyvus]. [žiūrèta 2013-10-10]. < http://www.teismai.lt/lt/teismai/ teismai-statistika>.

5 Bužinskas, G. Europos Sajungos valstybių nacionalinės teisès ịtaka Lietuvos Respublikos darbo ginčų instituto reformai. Jurisprudencija. 2013, 20(3): 15.

$6 \quad$ Ibid.

7 Darbo byloms nagrinèti specializuotų teismų ịsteigimo Lietuvoje galimybès. Lietuvos Respublikos teisin- 
Vokietijoje darbo teismai turi išskirtinę jurisdikciją nagrinėti tas darbo bylas ${ }^{8}$, kuriose kilusiam ginčui yra taikomas Darbo teismų įstatymas ${ }^{9}$. Vokietijoje specializuoti darbo teismai atsirado XIX a. pradžioje (pirmieji Europoje). Darbo teismų veikla čia remiasi trišalio bendradarbiavimo principu, kadangi teismines bylas nagrinèja kolegijos, susidedančios iš profesionalių ir neprofesionalių teisėjų, teikiamų profesinių sajungų ir darbdavių organizacijų. Tokia įvairi teismo sudètis leidžia užtikrinti visapusišką, kvalifikuotą ir nešališką darbo ginčo nagrinèjimą. „Darbo teismai nagrinèja bylas, kylančias dèl nesutarimų tarp kolektyvinès sutarties šalių arba tarp šalių ir trečiųjų asmenų. Jie taip pat nagrinėja ginčus dèl kolektyvinès sutarties egzistavimo ar neegzistavimo fakto nustatymo, civilinius ginčus, bet tik tarp specialių subjektų - darbuotojų ir darbdavių. İstatymo normos suformuluotos taip, kad skatintų pažeistus interesus ginti darbo teismuose." $" 10$

Ispanijoje egzistuoja tam tikras padalijimas i jurisdikcines sritis - civilinę, baudžiamąją, administracinę ir socialinę. ,Socialinių reikalų teismai - tai organai, paprastai pirmojoje instancijoje nagrinejjantys ginčus darbo bei socialinės saugos srityse. Jų sprendimai negali būti užginčyti nedidelès svarbos bylose (ieškiniai dèl sumų, neviršijančių 1803 eurų), kitais atvejais galioja teisè kreiptis su apeliaciniu ar ypatinguoju prašymu ị aukštesniųų teismų civilinių reikalų skyrius. Šie socialinių reikalų skyriai nagrinejja pirmojoje instancijoje kolektyvinius ginčus, apimančius ne vieną autonominės srities provinciją, dèl jų nutarimų gali būti paduodami kasaciniai skundai. Nacionalinio teismo socialinių reikalų skyrius nagrinèja kolektyvinius ginčus, apimančius ne vieną autonominę sriti. Aukščiausiojo teismo socialinių reikalų skyrius nagrinėja kasacinius skundus dèl Nacionalinio teismo bei aukštesniųjų teismų civilinių reikalų skyrių priimtų nutarimų, taip pat ,doktrinos vienumo pareiškimus“ dèl jų nutarimų apeliacinių prašymų atžvilgiu." ${ }^{\text {"11 }}$

Prancūzijoje $^{12}$ veikia mišrios kompetencijos darbo teismai, kurių ,,pasiskirstymas priklauso nuo atskirų teritorijų darbingų asmenų užimtumo lygio“"13. Darbo santykių teismas sprendžia individualius konfliktus tarp darbdavių ir darbuotojų dèl darbo sutarties ar sutarties dèl profesinès praktikos ir imasi veiksmų darbuotojo arba darbdavio prašymu, stengiasi sutaikinti šalis. Jis priima sprendimą tik jeigu taikinimas - privaloma procedūra, išskyrus įstatymo nustatytas išimtis, - neduoda rezultatų. Darbo santykių teismą sudaro renkami teisejjai, lygiomis dalimis atstovaujantys darbuotojams ir darbdaviams. Jis suskirstytas į 5 specializuotus skyrius: vadovavimas, pramonè, prekyba ir

gumo ministerijos Teisès institutas [interaktyvus]. Vilnius, 2003 [žiūrèta 2013-10-28]. <http://www3.lrs. lt/owa-bin/owarepl/inter/owa/U0118665.doc>.

8 Vokietijos darbo teismų jurisdikcija apima tiek individualių, tiek kolektyvinių darbo ginčų sprendimą.

9 Arbeitsgerichtsgesetz [interaktyvus]. [žiūrèta 2013-10-11]. <http://www.gesetze-im-internet.de/arbgg/ BJNR012670953.html>.

10 Bužinskas, G. Europos Sajungos valstybių nacionalinès teisès įtaka Lietuvos Respublikos darbo ginčų instituto reformai, supra note 6.

11 Europos teisminis tinklas civilinėse ir komercinėse bylose [žiūrèta 2013-12-04]. <http://ec.europa.eu/ civiljustice/org_justice/org_justice_spa_lt.htm>.

12 Ibid.

13 Elliott, C.; Vernon, C. French legal system. Longman, 2000, p. 64. 
prekybos paslaugos, žemės ūkis, kita veikla. Valstybės tarnautojai ar valstybės mokami darbuotojai turi kreiptis ị administracinị teismą.

Estijos darbo ginčų sprendimo modelis veikia nuo 1996 metų, įtvirtintas Estijos individualių darbo ginčų sprendimo ịstatymu ${ }^{14}$, kurị papildo $1996 \mathrm{~m}$. liepos $11 \mathrm{~d}$. Vyriausybès nutarimu patvirtinti Darbo ginčų komisijų nuostatai ${ }^{15}$. Aptariamas įstatymas Estijoje, skirtingai nei Lietuvoje, suteikia teisę darbuotojui ir darbdaviui pasirinkti vieną iš individualaus darbo ginčo nagrinėjimo organų - darbo ginčų komitetą arba teismą. Ir nors darbo ginčų komitetas Estijoje nèra privalomas pirminis - ikiteisminis individualių darbo ginčų nagrinejjimo organas, tačiau yra labai populiarus, kadangi neteisminèje institucijoje darbo bylos išnagrinejjamos daug greičiau negu teisme, šalys išvengia bylinèjimosi išlaidų, teisminių procedūrų. 1998-2001 metais vidutiniškai teismuose buvo nagrinètos 607 darbo bylos per vienerius metus, o komisijose 2000-2002 metais buvo išnagrinėti vidutiniškai 3200 darbo ginčai per metus ${ }^{16} .2009$ metais darbo ginčų skaičius darbo ginču komitetuose jau buvo arti 8000 per metus ${ }^{17}$, kas rodo Estijos individualių darbo ginčų nagrinejjimo tvarkos reformos pasiteisinimą.

Trumpai aptariant kai kurių Europos Sajungos šalių praktiką nagrinėjant individualius darbo ginčus visų pirma reiktų pabrèžti, jog kiekvienoje šalyje darbo ginčų sprendimo sistemos yra skirtingos ir išskirti vieną idealiausią būtų objektyviai sunku. Darbo ginčų nagrinejjimas skirtingose šalyse yra nacionalinio reguliavimo klausimas. Vienose veikia specializuoti darbo teismai, kitose - teismams alternatyvios ikiteisminès institucijos. Ir nors Vakarų Europos valstybėse nėra ikiteisminių individualių darbo ginčų nagrinèjimo institucijų, tačiau darbo ginčų šalių taikinimui yra skiriamas didelis demesys. Alternatyvius darbo ginčų sprendimo būdus aktyviai skatina Europos Sajungos institucijos: „Europos Komisija 2002 m. pristatė alternatyvių ginčų sprendimų būdų civilinèse ir komercinèse bylose ,žaliają knygą“, Europos Tarybos Ministrų komitetas 1998-2002 metais prièmė keturias rekomendacijas sutaikymo ir tarpininkavimo klausimais šeimos, civilinėse, administracinèse ir baudžiamosiose bylose ${ }^{\text {"18 }}$. Ir nors konkrečiai apie darbo ginčų sprendimo būdus nėra užsimenama, tačiau aiškiai matoma bendroji Europos Sąjungos nuomonė ginčus spręsti taikiai, kompromiso būdu.

Lietuvoje iki 2013 metų galiojusi individualių darbo ginčų nagrinejjimo tvarka, veikusi gamybiniu principu, buvo neefektyvi, todèl buvo būtina ieškoti išeities. Lietuva nebuvo pajègi be išlygų perimti vienos ar kitos valstybių darbo ginčų sprendimo sistemos

14 Individual Labour Dispute Resolution Act 1995-12-20 [interaktyvus]. [žiūrèta 2013-10-11]. <http://www. legaltext.ee/en/andmebaas/ava.asp?m=026 // <http://www.legaltext.ee/text/en/X1040K2.htm>.

15 Decree No. 186 of 11 July 1996 to adopt Regulations on the Commission in charge of labour disputes [interaktyvus]. [žiūrèta 2013-10-11]. <http://www.ilo.org/dyn/natlex/natlex_browse.details?p_lang=en\&p_ country $=$ EST\&p_classification $=02 \& p \_$origin $=$SUBJECT $>$.

16 Labour dispute resolution process examined [interaktyvus]. [žiūrèta 2013-10-11]. <http://www.eurofound.europa.eu/eiro/2004/02/feature/ee0402102f.htm>.

17 Jubilee of the Labour Dispute Committees of the Labour inspectorate: 15 years of ,free court“ [interaktyvus]. [žiūrèta 2013-05-28]. <http://www.ti.ee/index.php?article=id/2011\&page=1526\&action=article\&>.

18 Judickienè, J. Darbo ginčų nagrinejjimas socialinio ir trišalio bendradarbiavimo principų igyvendinimo aspektu. Teisé. 2003, 47: 54. 
modelio, tačiau pritaikyti kai kuriuos aspektus remiantis pačios Lietuvos bei užsienio šalių patirtimi - buvo būtina.

\section{3. $2013 \mathrm{~m}$. sausio $1 \mathrm{~d}$. individualių darbo ginčų sprendimo reforma}

Lietuva didžiausią dėmesị skyrè Estijos darbo ginčų sprendimo modelio analizei. Galbūt ir dèl to, jog Estija buvo pirmoji iš Baltijos šalių po nepriklausomybès atkūrimo pradejusi darbo ginčų instituto reformą ir gana sėkmingai ją realizavusi. 2012 m. birželio 26 d. Lietuvos Respublikos Seimas pritarè Socialinès apsaugos ir darbo ministerijos iniciatyvai keisti individualių darbo ginčų nagrinejjimo tvarką. Naujaja tvarka buvo siekiama padaryti darbo ginčų nagrinėjimą kiek įmanoma efektyvesnį, prieinamesnị darbuotojui, skaidresni, i pagalbą pasitelkiant socialinius partnerius.

Lietuvos Respublikos Konstitucijos ${ }^{19} 48$ straipsnis ịtvirtina žmogaus laisvę pasirinkti darbą, teisę turèti tinkamas, saugias ir sveikas darbo sąlygas. Valstybès valdžios institucijos privalo užtikrinti šių konstitucinių reikalavimų ígyvendinimą. DK 286 straipsnis numato, jog nesutarimas tarp darbdavio ir darbuotojo yra laikomas individualiu darbo ginču. Tokius ginčus nagrinèja du organai - teismas ir darbo ginčų komisija ${ }^{20}$.

DGK yra privalomas ikiteisminis organas darbo ginčams dèl neišmokèto ar neteisingai išmokèto darbo užmokesčio išieškojimo, drausminès nuobaudos panaikinimo, darbo įstatymų pažeidinèjimo, darbdavio ar darbuotojo įsipareigojimų nevykdymo ar netinkamo jų vykdymo, materialinės atsakomybės klausimų. DK 299 straipsnyje pateiktas pavyzdinis kreipimosi ị teismą aplinkybių sąrašas, t. y. darbuotojai ar darbdaviai iš karto ị teismą gali kreiptis tik dèl darbuotojo nušalinimo nuo darbo darbdavio iniciatyva, dèl darbuotojo nušalinimo nuo darbo pareigūnų ar organų, kuriems įstatymai suteikia nušalinimo nuo darbo teisę, iniciatyva, dèl darbuotojo atleidimo iš darbo teisètumo ${ }^{21}$. Šis sąrašas, galima manyti, nebaigtinis, kadangi aptariamo straipsnio 2 dalies 4 punktas numato ir kitus įstatymo nustatytus atvejus. Pavyzdžiui, pagal DK 96 straipsnị ginčai dèl įdarbinimo pagal Lietuvos Respublikos Konstitucijos 30 straipsnị ir pagal Lietuvos Respublikos civilinio kodekso (toliau - CK) 6.250 straipsnị, ginčai dèl neturtinès žalos atlyginimo pagal Lietuvos Respublikos lygių galimybių ịstatymo ${ }^{22}$ nuostatas, klausimai dèl diskriminacijos darbo teisiniuose santykiuose - nagrinëjami tiesiogiai teisme ${ }^{23}$.

Šiuo metu Lietuvoje teritoriniu principu veikia 13 darbo ginčų komisijų: 4 - Vilniuje, 3 - Kaune, 2 - Klaipėdoje, po 1 - Šiauliuose, Panevėžyje, Alytuje ir Telšiuose.

19 Lietuvos Respublikos Konstitucija. Valstybès žinios. 1992, Nr. 33-1014.

20 Lietuvos Respublikos darbo kodekso XIX skyriaus pakeitimo įstatymas. Valstybės žinios. 2012, Nr. 804138 .

21 Ibid.

22 Lietuvos Respublikos lygių galimybių ịstatymas. Valstybės žinios. 2003, Nr. 114-5115. „Kaip vykdomas šis ịstatymas prižiūri bei skundus dèl galimos diskriminacijos nagrinèja lygių galimybių kontrolierius Lietuvos Respublikos moterų ir vyrų lygių galimybių įstatymo nustatyta tvarka“ - 14 ir 15 straipsniai.

23 Darbo ginčų komisijos 2013 m. kovo 7 d. sprendimas darbo byloje Nr. APS-36-2830/2013. 
Utenos, Marijampolès, Tauragès apskritis aptarnauja atitinkamai Vilniaus, Kauno, Klaipėdos komisijos. DGK pagrindinis tikslas yra sutaikyti darbo ginčo šalis ${ }^{24}$, taip skatinant socialinès partnerystės tarp darbuotojų ir darbdavių plètojimą.

Tai, jog i DGK gali kreiptis ne tik darbuotojas, bet ir darbdavys, išties sulygino darbo teisinių santykių šalių teises bei galimybes, kadangi pagal anksčiau galiojusias DK nuostatas, kreiptis į komisiją turèjo teisę tik darbuotojas, o darbdavys - be išlygų i teismą.

Asmuo, kreipdamasis i komisiją, turi pateikti nustatytos formos prašymą ${ }^{25}$ (prašymo forma yra rekomendacinio pobūdžio, kiekviename VDI teritoriniame skyriuje šios formos yra išduodamos nemokamai). Prašyme turi būti nurodoma ieškovo, atsakovo vardai, pavardès ir adresai, o tais atvejais, kai dalyvauja juridinis asmuo, - jo pavadinimas, buveinès adresas ir kodas. DK 289 straipsnyje imperatyviai nurodoma, jog prašyme turi būti nurodomos aplinkybès, pagrindai ir ịrodymai, kuriais ieškovas grindžia savo reikalavimus, pateikiamas suformuluotas reikalavimas, pridedamų dokumentų sąrašas $^{26}$. Kaip matyti, įstatymas prašymo turiniui nekelia specialių reikalavimų, kaip kad ieškiniui civiliniame procese. Prašymo turinys gana paprastas ir jame prašoma nurodyti tik minimalią informaciją. Tačiau kyla klausimas, ar gali komisijos sekretorius, kuris priima ir registruoja prašymus, atsisakyti priimti prašymą, neatitinkantị tokių minimalių ịstatymo keliamų reikalavimų? DK taip pat nenumato prašymo trūkumų šalinimo instituto. Remiantis Lietuvos Respublikos civilinio proceso kodekso (toliau - CPK) analogija ieškinio trūkumų šalinimo procesas nebebūtų toks greitas ir paprastas, kas suponuoja išvadą, jog komisijos sekretoriui įstatymų leidèjas netiesiogiai suteikè gana plačią diskrecijos teisę priimant prašymą nuspręsti, ar jo turinys tinkamas. Pažymėtina, jog komisiją aptarnaujantis sekretorius, DGK pirmininko pavedimu, remiantis DK 288 straipsnio 3 dalimi, pats gali išreikalauti prašymui išnagrinèti reikiamus dokumentus. Praktikoje pasitaiko, jog komisijos gauna prašymus rusų, anglų kalbomis, net be reikalaujamų svarbiausių duomenų, ir tokie prašymai yra priimami. Istatymo leidèjas nenumate, kokiais atvejais DGK gali atsisakyti priimti prašymą. Siekiama, jog, kreipimosi ị komisiją procedūra būtų patogi, todèl supaprastinama kreipimosi tvarka, tačiau reglamentavimas nepakankamai išsamus, praktikoje neišvengiama teisinių kazusų, juos trumpai aptarsime.

Prašymai nagrinėjami toje VDI teritorinio skyriaus veiklos teritorijoje esančioje DGK, kurioje registruotas atsakovas, tačiau, remiantis CPK 411 straipsnio nuostatomis $^{27}$, darbuotojo prašymas taip pat gali būti paduodamas pagal vietą, kurioje darbas yra, buvo ar turèjo būti dirbamas. Kadangi komisijos veikia vieno langelio principu ${ }^{28}$, prašy-

24 Valstybinè darbo inspekcija prie Socialinès apsaugos ir darbo ministerijos [žiūrèta 2013-10-18]. <http:// www.vdi.lt/DGK/DGK.aspx>.

25 Valstybinè darbo inspekcija prie Socialinès apsaugos ir darbo ministerijos [žiūrèta 2013-10-11]. < http:// www.vdi.lt/kontaktai/DGK/dgk.aspx>.

26 Lietuvos Respublikos darbo kodekso XIX skyriaus pakeitimo ịstatymas, supra note 20, 289 straipsnis.

27 Lietuvos Respublikos civilinio proceso kodeksas. Valstybès žinios. 2002, Nr. 36-1340.

28 Lietuvos Respublikos viešojo administravimo įstatymas. Valstybès žinios. 1999, Nr. 60-1945, 3 straipsnio 8 punktas: vieno langelio principas reiškia, kad asmeniui informacija suteikiama, prašymas, skundas ar pranešimas priimamas ir atsakymas ị juos pateikiamas vienoje darbo vietoje. Prašymą, skundą ar prane- 
mus galima paduoti ị artimiausią VDI teritorinị skyrių, o toliau prašymas bus nukreiptas i atitinkamą VDI teritorinị skyrių pagal atsakovo registracijos vietą arba, kaip minėta, pagal vietą, kurioje darbas yra, buvo ar turèjo būti dirbamas. Atkreiptinas dėmesys, kad toks įstatymo suteikiamas patogumas šalims atveria kelią vienu metu kreiptis i kelias DGK, todèl būtina sukurti skundų registravimo informacinę bazę, siekiant išvengti tos pačios bylos nagrinèjimo keliose komisijose.

Kaip minėta, DGK veikia trišaliu principu - sprendimus bendru sutarimu priima komisijos pirmininkas, po vieną iš darbdavių ir darbuotojų atstovą. Tokia sistema leidžia komisijoms dirbti objektyviai - sprendžiant darbo ginčą komisija susideda iš trijų komisijos narių, iš jų du - socialiniai partneriai. DGK pirmininką skiria Lietuvos Respublikos vyriausiasis valstybinis darbo inspektorius, kiti du komisijos nariai skiriami iš VDI teritorinių skyrių veiklos teritorijoje veikiančių profesinių sajungų ir darbdavių organizacijų atstovų. Socialiniai partneriai - t. y. darbuotojų ir darbdavių atstovai, atleidžiami nuo darbo pareigų atlikimo laikotarpiui, per kurị jie dalyvauja darbo ginčų komisijos darbe ${ }^{29}$. Už vieną dirbtą valandą DGK posėdyje kiekvienam darbuotojų ir darbdavių atstovui sumokamas 25 Lietuvos Respublikos Vyriausybės patvirtintų bazinių valandinių atlygių dydžio atlygis (šiuo metu tai 18,26 Lt) ${ }^{30}$. Verta pažymėti, jog nei DK, nei kiti komisijų veiklą reglamentuojantys norminiai teisės aktai komisijos nariams, t. y. darbuotojų ir darbdavių atstovams, specialių kompetencijos reikalavimų nekelia. Todèl kyla klausimas, ar darbuotojų ir darbdavių paskirti atstovai yra pakankamai kompetentingi nagrinèti darbo ginčus? Juk DGK veikla yra siejama su darbo teisinius santykius reglamentuojančių įstatymų bei kitų teisès aktų taikymu, pažeistų teisių ir interesų gynimu, kam reikia specialių žinių. İstatymų leidèjas specialių reikalavimų nekelia, tad DGK pirmininkas gali būti vienintelis žmogus, turintis teisinị išsilavinimą.

Per vienus darbo metus komisijos išnagrinėjo 4688 prašymus, tuo tarpu teismai 2012 metais gavo 2144 reikalavimus dèl individualių darbo santykių, 2011 metais 2059 reikalavimus, 2010 metais $-3059,2009$ metais $-3860^{31}$. Ši statistika rodo individualių darbo santykių reikalavimų mažejjimą teismuose, o komisijos prašymų išnagrinèti darbo ginčą per 2013 metus gavo daugiau, nei dvigubai, lyginant su teismais 2012 metais, kas rodo pasitikèjimą komisijų veikla. Absoliuti dauguma prašymų DGK pateikta dèl darbo užmokesčio ir su juo susijusių sumų išieškojimo, taip pat teikiami prašymai dèl drausminių nuobaudų panaikinimo, materialinės atsakomybès pritaikymo, ipareigojimo nutraukti darbo sutartị, darbo ir poilsio laiko režimo nustatymo ir pan. Per pirmuosius darbo metus darbo ginčo šalys komisijose sudarė apie 554 taikos sutartis.

šimą nagrinèja ir informaciją iš savo administracijos padalinių, pavaldžių subjektų, prireikus - ir iš kitų viešojo administravimo subjektų gauna pats prašymą, skundą ar pranešimą nagrinèjantis ir administracinị sprendimą priimantis viešojo administravimo subjektas, neịpareigodamas to atlikti prašymą, skundą ar pranešimą padavusị asmenị.

29 Lietuvos Respublikos darbo kodekso XIX skyriaus pakeitimo įstatymas, supra note 20, 288 straipsnis.

30 Lietuvos Respublikos socialinès apsaugos ir darbo ministro įsakymas „Dėl Darbo ginčų komisijos nuostatų, Darbo ginčų komisijos darbo reglamento bei Atlygio mokejjimo darbuotojų ir darbdavių atstovams darbo ginčų komisijose ir kelionès išlaidų apmokèjimo tvarkos aprašo patvirtinimo“. Valstybés žinios. 2012, Nr. 143-7398.

31 Teismų statistika [žiūrèta 2013-10-30]. < http://www.teismai.lt/lt/teismai/teismai-statistika/>. 


\section{Terminas kreiptis į darbo ginčų komisiją - 3 metai ar 3 ménesiai?}

Naujai įsigaliojusi tvarka supaprastino kreipimąsi ị DGK, tačiau ir užminė papildomų mịslių. Viena iš pirmųjų pastebėtų problemų - pažeistos asmens teisės gynimo terminai. İstatymai nustato keletą skirtingų terminų. DK 289 straipsnyje numatyta, jog darbuotojas ar darbdavys rašytini prašymą nagrinèti darbo ginčą komisijai gali pateikti per 3 mènesius nuo tos dienos, kai sužinojo ar turejjo sužinoti, kad pažeistos jo teisès. Ši teisès norma konkuruoja su DK numatytu bendruoju 3 metų ieškinio senaties terminu bei praktikoje painiojama su DK 301 straipsnio specialiaja norma, kuri nustato, jog „darbuotojui priklausančios darbo užmokesčio ir kitos su darbo santykiais susijusios sumos priteisiamos ne daugiau kaip už 3 metus“'32. Kyla klausimas - kada taikomas 3 metų, o kada 3 mẻnesių terminas pažeistai darbo teisei ginti? Ieškant atsakymo ị ši klausimą, DGK vadovaujasi proceso koncentruotumo ir ekonomiškumo principais bei formuoja nevienodą praktiką. Pavyzdžiui, Vilniaus antroji DGK taiko specialią normą, nustatytą DK 289 straipsnio 1 dalyje, t. y. trijų ménesių kreipimosi ị komisiją terminą ${ }^{33}$, remdamasi teismų aiškinimu, kur nurodoma, kad 3 metų ieškinio senaties terminas yra skirtas dèl kreipimosi ginti pažeistą teisę, o trijų mènesių - siejamas su subjektinès teisès turējimu. Ieškinio senaties termino paskirtis - skatinti darbuotojus laiku domėtis jiems priklausančiomis išmokomis, elgtis atidžiai ir rūpestingai savo teisių atžvilgiu, todèl ịstatymo leidejjas ir numatẻ terminus, kuriems pasibaigus išnyksta teisé ị pažeistos teisès gynybą teikiant ieškini i ${ }^{34}$. Vilniaus miesto apylinkès teismas yra pasisakęs, jog „triju mènesių terminas, atsižvelgiant ị Darbo kodekso pakeitimų turinį ir pobūdị, turi būti skaičiuojamas nuo atitinkamų ịstatymo pakeitimo ịsigaliojimo dienos, t. y. nuo $2013 \mathrm{~m}$. sausio $1 \mathrm{~d}$. Priešingu atveju, būtų iš esmès paneigta teisè ginti pažeistas darbo teises" ${ }^{\text {“35 }}$.

Taigi, darytina išvada, jog nuo $2013 \mathrm{~m}$. sausio $1 \mathrm{~d}$. galioja 3 mėnesių procedūrinis senaties terminas kreiptis ị darbo ginčų komisiją, tačiau jis gali būti atnaujintas, esant motyvuotam ieškovo prašymui.

Vadovaujantis DK 289 straipsnio 1 dalimi, praleistas prašymo pateikimo terminas gali būti atnaujintas komisijos sprendimu, jeigu prašyme nurodytos termino praleidimo priežastys DGK pripažịstamos svarbiomis. Kiekvienu konkrečiu atveju komisijos atsižvelgia ị faktines bylos aplinkybes ir šalies nurodytas termino praleidimo priežastis, taip pat ị pareikštą prašymą dèl senaties termino atnaujinimo, remiantis CPK 78 straipsnio 1 dalies nuostatomis, kurios numato galimybę atnaujinti praleistą senaties terminą „dèl svarbių priežasčių ${ }^{36 " ، . ~ I ̇ s t a t y m e ~ n e n u r o d y t a ~ s a ̨ v o k o s ~ „ s v a r b i o s ~ p r i e z ̌ a s t y s “ ~ r e i k s ̌ m e ̀, ~ t o d e ̀ l ~}$ kiekvienu konkrečiu atveju svarbias priežastis nustato pati komisija, vadovaudamasi

32 Lietuvos Respublikos darbo kodeksas, supra note 2, 301 straipsnis.

33 Darbo ginčų komisijos 2013 m. kovo 21 d. sprendimas darbo byloje Nr. APS-36-3239/2013 ir 2013 m. spalio 15 sprendimas darbo byloje Nr. APS-36-16258/2013.

34 Vilniaus miesto apylinkès teismo $2013 \mathrm{~m}$. birželio10 d. sprendimas civilinèje byloje Nr. 2-14099$803 / 2013$.

35 Vilniaus miesto apylinkès teismo 2013 m. liepos 5 d. sprendimas civilinèje byloje Nr. 2-20249-905/2013.

36 Lietuvos Respublikos civilinio proceso kodeksas, supra note 27. 
teisingumo, protingumo ir sąžiningumo principais, atsižvelgiant ị įstatyme nustatyto termino tikslus, konkrečias faktines darbo bylos aplinkybes, dèl kurių šis terminas buvo praleistas, taip pat ị kitas reikšmingas darbo bylos aplinkybes. Teismų praktikoje svarbiomis priežastimis, dèl kurių gali būti atnaujinamas praleistas terminas, dažniausiai pripažįstama ,pareiškimą padavusio asmens liga, laikinas išvykimas iš nuolatinès gyvenamosios vietos, îvairios stichinès nelaimès, suklydimas ir panašios aplinkybès. Liga pati savaime nèra laikoma svarbia procesinio termino praleidimo priežastimiic37. Teismai atnaujina ${ }^{38} 3$ mėnesių kreipimosi ị komisiją terminą, remdamiesi DK 289 straipsnio 1 dalimi, kuri suteikia teisę pačiai komisijai spręsti dẻl praleisto termino atnaujinimo, kadangi pagal kasacinio teismo formuojamą praktiką ,,tais atvejais, kai asmuo aktyviais ir teisètais veiksmais per visą ieškinio senaties laiką ir praejjus senaties terminui, iki pat bylos iškèlimo teisme norèjo atgauti pinigus, o skolininkas per visą tą laiką skolą pripažino, nėra pagrindo tikètis, kad kreditorius atsisako savo teisès ị pinigų susigrąžinimą, todèl tokie veiksmai laikytini, jog ieškinio senaties termino eiga buvo nutraukta. Istatymas suteikia teisę atnaujinti ne naikinamajj terminą, o atnaujinus terminą, pažeistoji teisè turi būti ginama tam, kad būtų apginti sąžiningų asmenų teisèti interesai, o skolininkas, negrąžinęs skolos per sutartyje nustatytą terminą ir toliau elgdamasis nesąžiningai, neturètų išvengti prievolès įvykdymo remdamasis vien ieškinio senaties terminu“"39.

Vilniaus teritorinio skyriaus ketvirtoji DGK laikosi pozicijos, jog ,aiškinant sistemiškai, procedūriniai terminai kreiptis i darbo ginčų komisiją bei ieškinio senaties terminai turi būti tapatūs. Darbo kodekso 289 str. 1 d. nustatytas 3 mènesių terminas taip pat laikomas senaties terminu ir taikomas tik neturtinio pobūdžio reikalavimams pareikšti (dèl drausminès nuobaudos panaikinimo, darbo sutarties sąlygų neteisèto pakeitimo, kt.), nes išimtis (trumpesnis senaties terminas) negali paneigti bendros taisyklès, jog bendrasis senaties terminas darbiniuose santykiuose yra 3 metai. Vilniaus teritorinio skyriaus trečioji DKG laikosi nuomonès, jog, nelogiška teigti, kad esant 3 metų ieškinio senaties terminui turtiniams reikalavimams pareikšti kreipimuisi ị darbo ginčų komisiją yra taikomas 3 mėnesių terminas ${ }^{40}$. Ta pati DGK laikosi pozicijos, jog, ,išimtis negali visai išeliminuoti bendros taisyklès, todèl aptariama kolizija aiškintina taip, kad turtiniams darbo ginčams taikomas bendras ieškinio senaties terminas - 3 metai, o neturtiniams darbo ginčams (dèl drausminès nuobaudos panaikinimo, neteisèto perkèlimo ị kitą darbą, kt.) - sutrumpintas 3 mėnesių ieškinio senaties terminas ${ }^{\text {"“41 }}$.

Taigi, kaip matyti iš anksčiau aptartų DGK sprendimų bei esamos teismų praktikos, iki šiol nėra suformuota viena pozicija dẻl terminų, minètos civilinès bylos šiuo metu dar nagrinejjamos apeliacine tvarka. Nesant vienodos praktikos, skirtingose DGK priimami nevienodi sprendimai, asmenims nèra aišku, ar tapatūs reikalavimai skirtingose

37 Lietuvos Aukščiausiojo Teismo Civilinių bylų skyriaus teisèjų kolegijos $2000 \mathrm{~m}$. lapkričio 15 d. nutartis civilinèje byloje Nr. 3K-3-1172/2000.

38 Vilniaus miesto apylinkès teismo $2013 \mathrm{~m}$. birželio 10 d. sprendimas civilinėje byloje Nr. 2-14099$803 / 2013$.

39 Lietuvos Aukščiausiojo Teismo Civilinių bylų skyriaus teisèjų kolegijos $2006 \mathrm{~m}$. gruodžio 4 d. nutartis, priimta civilinèje byloje $R$. A. S. v. L. G. (bylos Nr. 3K-3-621/2006).

40 Darbo ginčų komisijos 2013 m. liepos 3 d. sprendimas darbo byloje Nr. APS-1-10070/2013.

41 Darbo ginčų komisijos 2013 m. vasario 3 d. sprendimas darbo byloje Nr. APS-1-1105/2013. 
komisijose būtų išnagrinèti vienodai. İstatymų leidèjui būtina kuo skubiau panaikinti susidariusią įstatymo koliziją, kuri, anot prof. G. Bužinsko, sukuria dvigubus standartus ginant pažeistas darbines teises ${ }^{42}$. Pavyzdžiui, Estijoje ginčams dèl darbo užmokesčio išieškojimo yra taikomas 3 metų ieškinio senaties terminas, o dèl darbo sutarties nutraukimo - tik 1 ménuo, dẻl pažeistų darbo teisių -4 mėnesiai ${ }^{43}$. Kyla klausimas - kada apskritai taikomas DK 27 straipsnio nustatytas 3 metų ieškinio senaties terminas? Siūlytume DK 27 straipsnyje taip pat įtvirtinti 3 mènesių ieškinio senaties terminą, kuris būtų skaičiuojamas nuo pažeidimo arba sužinojimo apie asmens teisès pažeidimą dienos. Vienodas terminas neleistų šalims piktnaudžiauti, delsti, taip būtų ịtvirtintas 3 mènesių senaties terminas kreiptis tiek ị DGK, tiek ị teismą, būtų užtikrinamas greitas kilusio darbo ginčo sprendimas. Šalys būtų suinteresuotos nedelsti kreiptis ị ginčą nagrinëjančius organus. Jei paaiškètų, jog, pavyzdžiui, darbuotojas žinojo faktą apie savo pažeistą teisę ir delsè kreiptis - ginčą nagrinèjantis organas galètų pripažinti praleistą terminą, o jei nežinojo - galètų taikyti DK 301 straipsnị ir priteisti susijusias sumas ne daugiau kaip už trejus metus.

\section{Darbo ginčų komisijos kompetencijos problema}

Vadovaujantis DK XIX skyriaus nuostatomis DGK nagrinèja nesutarimus tarp darbuotojo ir darbdavio dèl darbo ịstatymuose, kituose norminiuose teisès aktuose, darbo ar kolektyvinejje sutartyje nustatytų teisių ir pareigų igyvendinimo. Praktikoje iškyla klausimai dèl ginčų, susijusių su darbo santykiais, kuriuos šalys tikisi nagrinèti DGK. Tačiau pagal DK 290 straipsnio 1 dalies 3 punktą DGK atsisako nagrinèti prašymą, jeigu reikalavimo nagrinèjimas nepriskiriamas darbo ginčų komisijos kompetencijai, t. y.:

- kai darbdaviui yra iškelta bankroto byla, kadangi ịmonių bankroto procedūra yra vykdoma vadovaujantis Lietuvos Respublikos įmonių bankroto įstatymo nuostato$\mathrm{mis}^{44}$ ir ieškovas minèto ịstatymo pagrindais yra ịtraukiamas ị ịmonès kreditorių sąrašą. Pažymėtina, jog darbuotojų reikalavimai, susiję su darbo santykiais, yra tenkinami pirmaja eile ${ }^{45}$. Kai įmonè neturi pakankamai nuosavų lěšų atsiskaityti su darbuotojais, bankrutuojančios ar bankrutavusios įmonès administratorius pagal Lietuvos Respublikos garantinio fondo įstatymo nuostatas per du mènesius nuo kreditorinių reikalavimų patvirtinimo dienos Garantinio fondo nuostatų nustatyta tvarka privalo pateikti Garantinio fondo administratoriui dokumentus dèl lěšų skyrimo darbuotojų reikalavimams, susijusiems su darbo santykiais, tenkinti ${ }^{46}$;

42 Bužinskas, G. Ikiteisminis individualių darbo ginčų nagrinèjimas. Darbo teisè suvienytoje Europoje. Mokslinès konferencijos medžiaga. Vilnius: Forzacas, 2004, p. 294.

43 Individual Labour Dispute Resolution Act [interaktyvus]. [žiūrèta 2013-12-08]. <http://www.legaltext.ee/ text/en/X1040K2.htm>.

44 Plačiau žr. Lietuvos Respublikos įmonių bankroto ịstatymas. Valstybès žinios. 2001, Nr. 31-1010.

45 Ibid., 35 straipsnio 2 dalis.

46 Lietuvos Respublikos garantinio fondo įstatymas. Valstybès žinios. 2000, Nr. 82-2478, 6 straipsnio 1 dalis. 
- kai darbdaviui yra iškelta restruktūrizavimo byla, remiantis Lietuvos Respublikos įmonių restruktūrizavimo ịstatymo nuostatomis ${ }^{47}$. Ivvykdžius restruktūrizavimo planą, pirmaja eile yra tenkinami darbuotojų reikalavimai, susiję su darbo santykiais (ịskaitant gyventojų pajamų mokestị ir valstybinio socialinio draudimo įmokas). Nors restruktūrizavimo metu sustabdomas palūkanų ir netesybų mokèjimas, sustabdomas išieškojimas pagal vykdomuosius dokumentus, tačiau komisijos laikosi nuomonès, jog „,priskaičiuotų išmokèjimui sumų išieškojimas ịgyvendintinas, nes neatsiskaitymas su ieškovu už atliktus darbus ir nemokejjimas su darbo santykiais susijusių išmokų traktuotina, kaip netesybos ir turi būti išieškomos privaloma tvarka“448. Tad iškèlus teisme restruktūrizavimo bylą, kreditoriai savo reikalavimus pateikia ịmonės administratoriui, iš kurio turi teisę gauti informaciją apie įmonès restruktūrizavimo bylos eigą;

- kai darbo ginčas kyla valstybès tarnyboje, remiantis Lietuvos Respublikos valstybės tarnybos įstatymo nuostatomis, pagal kurias ,,valstybės tarnautojas - fizinis asmuo, einantis pareigas valstybès tarnyboje ir atliekantis viešojo administravimo veiklą “49. Lietuvos Respublikos administracinių bylų teisenos įstatymas nustatyto, jog ,ginčus dèl teisès viešojo administravimo srityje sprendžia administracinis teismas“ (istatymo numatytais atvejais prašymas pirmiausia turi būti paduodamas administracinių ginčų komisijai) ${ }^{50}$;

- kai darbo bylos šalis yra užsienio šalies teisès subjektas, kadangi norminiai teisès aktai, kuriais grindžiama darbo ginčų komisijos veikla ${ }^{51}$, ,nesuteikia darbo ginčų komisijai teisès spręsti individualius darbo ginčus, kai atsakovas yra užsienio šalies teisès subjektas, turintis toje valstybejje savo nuolatinę buveinę ${ }^{652}$;

- kai reikalavimas keliamas dẻl neturtinès žalos atlyginimo vadovaujantis DK 250 straipsnio nuostatomis, pagal kurias „,darbo teisinių santykių šalių padarytos neturtinės žalos dydị kiekvienu atveju nustato teismas, vadovaudamasis LR civiliniu kodeksu“"53. Todèl ieškovai dèl atsakovo padarytos neturtinès žalos atlyginimo turi teisę kreiptis i teismą civilinio proceso tvarka ${ }^{54}$;

- kai reikalavimas keliamas dèl bylinèjimosi išlaidų atlyginimo, kadangi DK XIX skyrius nenumato galimybės atlyginti kitai šaliai bylinėjimosi išlaidų. CPK VII skyriaus nuostatos taikomos tik civiliniame procese ${ }^{55}$.

47 Plačiau žr. Lietuvos Respublikos įmonių restruktūrizavimo įstatymas. Valstybès žinios. 2001, Nr. 311012.

48 Darbo ginčų komisijos 2013 m. gegužès 16 d. sprendimas darbo byloje Nr. APS-36-6687/2013.

49 Lietuvos Respublikos valstybès tarnybos įstatymas. Valstybès žinios. 1999, Nr. 66-2130, 2 straipsnio 2 dalis.

50 Lietuvos Respublikos administracinių bylų teisenos įstatymas. Valstybès žinios. 1999, Nr. 13-308, 3 straipsnis, 22 straipsnis.

51 Lietuvos Respublikos Konstitucija, Lietuvos Respublikos tarptautinès sutartys, Lietuvos Respublikos darbo kodeksas, Lietuvos Respublikos civilinio proceso kodeksas, Lietuvos Respublikos valstybinės darbo inspekcijos įstatymas, Darbo ginčų komisijos nuostatai.

52 Darbo ginčų komisijos 2013 m. gegužès 28 d. sprendimas darbo byloje Nr. APS-36-7160/2013.

53 Lietuvos Respublikos darbo kodekso XIX skyriaus pakeitimo įstatymas, supra note 20.

54 Darbo ginčų komisijos 2013 m. kovo 5 d. sprendimas darbo byloje Nr. APS-36-2623/2013 ir $2013 \mathrm{~m}$. gegužès 14 d. sprendimas darbo byloje Nr. APS-36-6406/2013.

55 Darbo ginčų komisijos 2013 m. balandžio 25 d. sprendimas darbo byloje Nr. APS-36-4873/2013. 
- kai reikalavimas keliamas dẻl palūkanų išieškojimo. Palūkanų skaičiavimą ir mokejjimą reglamentuoja CK nuostatos, pagal kurias ,terminą ịvykdyti piniginę prievolę praleidęs skolininkas privalo mokèti penkių procentų dydžio metines palūkanas už sumą, kurią sumokèti praleistas terminas, jeigu įstatymai ar sutartis nenustato kitokio palūkanų dydžio“"56. Komisijos teisès aktai, kuriais ji vadovaujasi savo veikloje, nesuteikia jai teisės nagrinėti ginčų, kylančių iš civilinių teisinių santykių, tarp jų ir ginčus dẻl palūkanų priteisimo, dèl kurių reiktų kreiptis ị bendrosios kompetencijos teismą su ieškiniư ${ }^{57}$;

- kai reikalavimas keliamas dèl laikinųjų apsaugos priemonių taikymo, kadangi DK XIX skyrius tokios galimybès nenumato, o ,Civilinio proceso kodekso penktojo skirsnio nuostatos taikomos tik civiliniame procese ${ }^{\text {" } 58 \text {; }}$

- kai reikalavimas keliamas dèl administracinès atsakomybès taikymo. Komisijos, pagal įstatymų, reglamentuojanti jų veiklą, neturi teisès kontroliuoti Lietuvos Respublikos įstatymų ir kitų norminių teisès aktų, reglamentuojančių darbo teisinius santykius, vykdymą ar/ir nustačius pažeidimus imtis administracinio poveikio priemonių pažeidimus padariusių kaltụjų asmenų atžvilgiu. Tokios teisès ir galimybès yra suteiktos pagal kompetenciją Valstybinės darbo inspekcijos teritorinių skyrių darbo inspektoriams. Todèl ,dèl darbo ịstatymų pažeidimų nustatymo, dẻl baudos paskyrimo už darbo isstatymų pažeidimus, dèl nelegalaus darbo fakto nustatymo, dèl darbo apmokèjimo ịmonèje organizavimo ir kt. nagrinejjimas ir sprendimų iš esmès šiais klausimais prièmimas yra VDI prerogatyva, todėl ieškovai su tokiais prašymais taikyti administracinę atsakomybę turi teisę kreiptis ị VDI su skundu dèl darbo įstatymų pažeidimų ${ }^{659}$.

Kaip matyti iš anksčiau aptartų klausimų, trūksta kai kurių gana svarbių procesinių klausimų (bylinėjimosi išlaidų atlyginimo, laikinųų apsaugos priemonių taikymo) reglamentavimo.

\section{Darbo ginčų komisijos sprendimo apskundimas ir vykdymas}

Kita kylanti problema - tolesni šalių veiksmai gavus nepalankų DGK sprendimą. Istatymo iniciatoriai norejjo apriboti šalių galimybes skųsti teismui DGK sprendimus ir siekẻ leisti kreiptis ị teismą tik suformulavus savarankiškus reikalavimus atskiru ieškiniu. Tačiau ìstatymo leidejjas DK 296 straipsnyje neaiškiai suformulavo tolesnius šalių, nepatenkintų DGK sprendimu, veiksmus. DK 296 straipsnis vadinasi „,Darbo ginču komisijos sprendimo apskundimas“, tačiau straipsnio turinys nustato, jog ,jeigu ginčo šalys nesutinka su darbo ginčų komisijos sprendimu, jos per mėnesị nuo darbo ginču komisijos sprendimo priëmimo dienos gali pareikšti ieškinị apylinkès teisme, vadovaudamosi Civilinio proceso kodekso nuostatomis“. DK 299 straipsnio 1 dalis taip pat

56 Lietuvos Respublikos civilinio proceso kodeksas, supra note 27, 6.210 straipsnio 1 dalis.

57 Darbo ginčų komisijos 2013 m. balandžio 23 d. sprendimas darbo byloje Nr. APS-36-5355/2013 ir 2013 m. birželio 25 d. sprendimas darbo byloje Nr. APS-3-9377/2013.

58 Darbo ginčų komisijos 2013 m. birželio 13 d. sprendimas darbo byloje Nr. 8215/2013.

59 Darbo ginčų komisijos sprendimas 2013 m. kovo 5 d. darbo byloje Nr. APS-36-2623/2013. 
numato, jog ,teismuose nagrinėjami apskųsti darbo ginčų komisijos sprendimai“60. Lingvistiniu požiūriu ,apskundimas aukštesnei instancijai arba kreipimasis ị aukštesnę instanciją persvarstyti kokị klausimą yra vadinamas apeliacija“"61. Tad DK kalbama apie komisijų sprendimų apskundimo institutą, tačiau aptartame DK 296 straipsnyje pateikiama DGK sprendimo apskundimo forma - ieškinys, kuris turi būti pareiškiamas apylinkès teismui, vadovaujantis CPK nuostatomis. Svarbu atkreipti dèmesị, jog minimas CPK 135 straipsnis numato tam tikrus ieškinio turinio reikalavimus ${ }^{62}$, tad darbuotojui nesutinkant su komisijos sprendimu ir skundžiant jị teismui prasideda sudètingas teisminis procesas. Tampa nebeaišku, ar toks komisijų sprendimų apskundimo reglamentavimas reiškia naujos bylos pradejjimą teisme, ar teismas tampa apeliacine instancija komisijų priimtiems sprendimams skųsti. Juk įstatyme numatomos teisinès definicjos turi realiai atspindèti reiškinị. Matyt, ịstatymo autoriai, sekdami Estijos pavyzdžiu, siekè neleisti skųsti DGK sprendimo teismui, o tarsi priversti ieškovus kreiptis su nauju ieškiniu ị teismą apginti pažeistą teisę. Tokiu būdu buvo siekiama išvengti nepagrịsto bylinèjimosi, kai suformuluoti reikalavimo neịmanoma, o siekiama tik skųsti priimtą DGK sprendimą. Istatymų leidèjui būtina nustatyti aiškią komisijų priimtų sprendimų apskundimo tvarką. Teisinès sąvokos turi būti vartojamos aiškiai, kad jos būtų suvokiamos kiek įmanoma tiksliau.

Nevienoda šio straipsnio taikymo praktika ir teismuose. Kai kurie teisèjai vadovaudamiesi DK 296 straipsnio nuostatomis savo sprendimuose DGK prilygina Ryšių reguliavimo tarnybai ${ }^{63}$, traukia DGK atsakovais ir prašo pateikti atsiliepimus toliau nagrinèjant darbo bylas teismuose ${ }^{64}$. Tokia teismų pozicija kelia diskusijų, kadangi komisijos neturi juridinio asmens statuso, yra sudaromos trišaliu principu iš darbdavių organizacijų, profsajunginių organizacijų ir VDI paskirtų atstovų, todėl, vadovaujantis CPK 41 straipsnio nuostatomis ${ }^{65}$, negali būti šalimi civiliniame procese. Be to, ir individualius darbo ginčus nagrinèjusios komisijos, sudaromos įmonèse iki 2013 m. sausio 1 d. pagal anksčiau galiojusị DK reglamentavimą, nebuvo ir negalèjo būti kviečiamos atsakovu teismuose nagrinèjamose bylose dèl šių komisijų sprendimų. Atsakovu bylose dèl savo priimtų sprendimų nèra ir patys teismai. VDI taip pat negali būti atsakovu darbo bylose, kadangi nieko bendro su nagrinèjamais darbo ginčais neturi, jokių veiksmų, turinčių reikšmę nagrinėjamose bylose ar/ir šalims, neatlieka. Atsižvelgiant ị tai, jog pagal DK nustatytą darbo ginčų nagrinėjimo tvarką teisme byla dẻl darbo ginčo yra nagrinèjama iš esmès, teikiant ieškinị, VDI nèra teisiškai suinteresuota bylos baigtimi, todèl nèra nei

60 Lietuvos Respublikos darbo kodeksas, supra note 2, 299 straipsnio 1 dalis.

61 Terminų žodynas [interaktyvus]. [žiūrèta 2013-10-29]. <http://www.zodynas.lt/terminu-zodynas/a/apeliacija $>$.

62 Lietuvos Respublikos civilinio proceso kodeksas, supra note 27.

63 Civilinėse bylose, kuriose Ryšių reguliavimo tarnyba nenagrinėjo ginčo išankstine sprendimo ne teisme tvarka, teismas ją gali įtraukti proceso dalyviu - Lietuvos Aukščiausiojo Teismo 2009 m. lapkričio $11 \mathrm{~d}$. nutartis civilineje byloje Nr. 3K3-480/2009.

64 Vilniaus miesto apylinkès teismo $2013 \mathrm{~m}$. spalio $1 \mathrm{~d}$. nutartis civilineje byloje Nr. 2-36676-852/2013 ir $2013 \mathrm{~m}$. spalio 26 d. nutartis civilinèje byloje Nr. 2-36843-582/2013.

65 Lietuvos Respublikos civilinio proceso kodeksas, supra note 27, 41 straipsnio 1 dalis (aktuali redakcija 2013-05-25). 
atsakovè, nei kita proceso dalyvė pagal CPK 37 ir 61 straipsnio nuostatas. Pagal Lietuvos Aukščiausiojo Teismo formuojamą praktiką, ,skundžiant išankstinės ne teismo tvarka administracinius ginčus nagrinejjančios kvaziteisminès institucijos - administracinių ginčų komisijų priimtus sprendimus, šalys teisme nesikeičia, o administracinių ginčų komisija byloje nedalyvauja“"66. Manoma, jog privaloma ikiteismine tvarka darbo ginčus nagrinėjančios komisijos veiklos pobūdis, organizavimas ir principai yra analogiški administracinių ginčų komisijai, todèl ginčus nagrinėjančios komisijos taip pat negali būti šalimi ir dalyvauti ikiteismine tvarka išnagrinėtose darbo bylose, kai tokios bylos toliau nagrinèjamos teisme.

Siekiant išvengti procesinių neaiškumų dẻl netobulos DK 296 straipsnio formuluotès, reikètų aiškios ịstatymo leidèjo nuostatos - kur ir kaip nagrinėjamas toliau ginčas po DGK sprendimo prièmimo.

DGK priimti sprendimai yra vykdomieji dokumentai, todèl po mėnesio, įsiteisèjus sprendimui ir atsakovui neįvykdžius sprendimo gražiuoju, ieškovas turi teisę tiesiogiai kreiptis ị antstolį dèl priverstinio sprendimo vykdymo pagal CPK nustatytą tvarką ${ }^{67}$.

\section{Išvados}

Iki 2013 m. sausio 1 d. individualių darbo ginčų nagrinėjimo tvarka nebuvo efektyvi. Darbdaviai dažnai ignoruodavo pareigą sudaryti darbo ginčų komisiją darbovietėse, todèl bendrosios kompetencijos teismai buvo apkrauti bylomis, o procesas buvo sudètingas, ilgas ir brangus. Ankstesnè statistika rodẻ santykinai nedideli darbo bylų skaičių teismuose, tačiau naujai veikiančiose darbo ginčų komisijose prašymų skaičius beveik padvigubėjo. Manome, jog darbuotojų teisès pagal senąją tvarką nebuvo veiksmingai ginamos, o naujoji individualių darbo ginčų nagrinejjimo tvarka pasiteisino. Tačiau praktikoje susiduriama su įvairiais trūkumais.

DK nėra numatytos prašymo trūkumų šalinimo tvarkos, įstatymo leidèjas taip pat nenumate, kokiais atvejais komisija gali atsisakyti priimti prašymą. Vadovaujantis CPK ieškinio trūkumų šalinimo analogija, procesas nebebūtų toks greitas ir paprastas, kas suponuoja išvadą, jog komisijos sekretoriui ịstatymų leidẻjas netiesiogiai suteikè gana plačią diskrecijos teisę priimant prašymą nuspręsti, ar jo turinys tinkamas.

Darbo ginčų komisijos narių kompetencijos klausimas neretai kelia darbo ginčo šalių nepasitikèjimą - ịstatymų leidèjas nekelia specialių reikalavimų socialinių partnerių atstovams, tad DGK komisijos pirmininkas gali būti vienintelis žmogus, turintis teisinị išsilavinimą.

66 Lietuvos Aukščiausiojo Teismo 2012 m. vasario 9 d. nutarimas administracinejje byloje Nr. A442138/2012 ir $2011 \mathrm{~m}$. balandžio $18 \mathrm{~d}$. nutarimas administracinèje byloje Nr. A146-71/2011.

67 Lietuvos Respublikos darbo kodekso XIX skyriaus pakeitimo įstatymas, supra note 20, 298 straipsnis. 
İstatymų leidejjui siūlytina kuo skubiau išspręsti klausimą dèl kreipimosi ị DGK termino. Siūlytume DK 27 straipsnyje įtvirtinti 3 mėnesių ieškinio senaties terminą, kuris būtų skaičiuojamas nuo pažeidimo arba sužinojimo apie asmens teisès pažeidimą dienos. Vienodas terminas neleistų šalims piktnaudžiauti, delsti, taip būtų įtvirtintas 3 mènesių senaties terminas kreiptis tiek ị DGK, tiek ị teismą, būtų užtikrinamas greitas kilusio darbo ginčo sprendimas.

Nèra aiškus darbo ginčų komisijų teisinis statusas. Teismai traukia komisijas atsakovais ir prašo pateikti atsiliepimus toliau nagrinėjant darbo bylas teismuose, nors pagal veiklos formą komisijos neturi juridinio asmens statuso, todèl negali būti šalimi civiliniame procese.

Darbo ginčų komisijoms taip pat trūksta aiškaus reglamentavo klausimuose dèl bylinèjimosi išlaidų atlyginimo, laikinujų apsaugos priemonių taikymo. Autorių nuomone, tai apsunkina darbo ginčų nagrinèjimo procesą.

Būtina nustatyti aiškią darbo ginčų komisijų priimtų sprendimų apskundimo tvarką. Pagal dabartinị reguliavimą neaišku, ar teismas yra apeliacinè instancija komisijų priimtiems sprendimams skųsti, ar komisijų sprendimų apskundimo reglamentavimas reiškia naujos bylos pradejjimą teisme. Manome, kad įstatymo leidejjas turi aiškiai dèl to apsispręsti ir nepalikti to spręsti precedento keliu Aukščiausiajam Teismui.

Siūlytina sukurti sistemą, kurioje butų kaupiami, analizuojami bei apibendrinami duomenys apie darbo ginčų komisijų priimtus sprendimus, kas leistų susipažinti su priimtais DGK sprendimais, matyti statistiką.

Iš pateiktų išvadų matyti, jog naujoji darbo ginčų sprendimo sistema pasiteisino, tačiau liko reglamentavimo spragų, kurioms spręsti reikalinga įstatymo leidejjo iniciatyva.

\section{Literatūra}

Bužinskas, G. Europos Sajungos valstybiu nacionalinès teisès įtaka Lietuvos Respublikos darbo ginčų instituto reformai. Jurisprudencija. 2013, 20(3).

Bužinskas, G. İstatymų, reguliuojančių darbo ginčų nagrinejjimą, tobulinimo kryptys. $J u$ risprudencija. 2002, 25 (17).

Bužinskas, G. Ikiteisminis individualių darbo ginčų nagrinejjimas. Darbo teisè suvienytoje Europoje. Mokslinès konferencijos medžiaga. Vilnius: Forzacas, 2004.

Darbo byloms nagrineti specializuotu teismu isteigimo Lietuvoje galimybès. Vilnius: Lietuvos Respublikos teisingumo ministerijos teisès institutas, 2003.

Darbo ginčų komisijos 2013 m. vasario 3 d. sprendimas darbo byloje Nr. APS-1-1105/2013.
Darbo ginčų komisijos 2013 m. kovo 5 d. sprendimas darbo byloje Nr. APS-36-2623/2013.

Darbo ginčų komisijos 2013 m. kovo 7 d. sprendimas darbo byloje Nr. APS-36-2830/2013.

Darbo ginču komisijos $2013 \mathrm{~m}$. kovo $21 \mathrm{~d}$. sprendimas darbo byloje Nr. APS-36-3239/ 2013.

Darbo ginčų komisijos 2013 m. balandžio $23 \mathrm{~d}$. sprendimas darbo byloje Nr. APS-36-5355/ 2013.

Darbo ginčų komisijos 2013 m. balandžio 25 d. sprendimas darbo byloje Nr. APS-36-4873/ 2013.

Darbo ginčų komisijos 2013 m. gegužès 14 d. sprendimas darbo byloje Nr. APS-36-6406/ 2013. 
Darbo ginčų komisijos 2013 m. gegužès 16 d. sprendimas darbo byloje Nr. APS-36-6687/ 2013.

Darbo ginčų komisijos 2013 m. gegužès 28 d. sprendimas darbo byloje Nr. APS-36-7160/ 2013.

Darbo ginčų komisijos 2013 m. birželio 13 d. sprendimas darbo byloje Nr. 8215/2013.

Darbo ginčų komisijos 2013 m. birželio 25 d. sprendimas darbo byloje Nr. APS-3-9377/ 2013.

Darbo ginčų komisijos 2013 m. liepos 3 d. sprendimas darbo byloje Nr. APS-1-10070/2013.

Darbo ginčų komisijos 2013 m. spalio 15 sprendimas darbo byloje Nr. APS-36-16258/2013.

Judickienè, J. Darbo ginčų nagrinėjimas socialinio ir trišalio bendradarbiavimo principu igyvendinimo aspektu. Teisé. 2003, 47.

Kiselev, I. Ja. Sravnitelnoe i mezhdunarodnoe trudovoe pravo [Comparative and international labor law]. Moskva, 1999.

Kiselev, I. Ja. Sravnitelnoe trudovoe pravo [Comparative Labor Law]. Moskva: Gosudarstvenij universitet, Vysshaja shkola ekonomiki, 2005.

Elliott, C.; Vernon, C. French legal system. Longman, 2000.

Lietuvos Respublikos Konstitucija. Valstybès žinios. 1992, Nr. 33-1014.

Lietuvos Aukščiausiojo Teismo Civilinių bylų skyriaus teisèjų kolegijos $2000 \mathrm{~m}$. lapkričio 15 d. nutartis civilineje byloje Nr. 3K-3$1172 / 2000$.

Lietuvos Aukščiausiojo Teismo Civilinių bylų skyriaus teisèjų kolegijos 2006 m. gruodžio 4 d. nutartis, priimta civilineje byloje $R$. A. S. v. L. G. (bylos Nr. 3K-3-621/2006).

Lietuvos Aukščiausiojo Teismo 2009 m. lapkričio $11 \mathrm{~d}$. nutartis civilineje byloje Nr. 3K3480/2009.

Lietuvos Aukščiausiojo Teismo 2011 m. balandžio $18 \mathrm{~d}$. nutarimas administracinèje byloje Nr. A146-71/2011.
Lietuvos Aukščiausiojo Teismo 2012 m. vasario 9 d. nutarimas administracineje byloje Nr. A442-138/2012.

Lietuvos Respublikos administracinių bylų teisenos įstatymas. Valstybès žinios. 1999, Nr. 13-308.

Lietuvos Respublikos civilinio proceso kodeksas. Valstybès žinios. 2002, Nr. 36-1340.

Lietuvos Respublikos garantinio fondo istatymas. Valstybès žinios. 2000, Nr. 82-2478.

Lietuvos Respublikos įmonių bankroto įstatymas. Valstybès žinios. 2001, Nr. 31-1010.

Lietuvos Respublikos įmonių restruktūrizavimo įstatymas. Valstybès žinios. 2001, Nr. 31-1012.

Lietuvos Respublikos lygiu galimybių ịstatymas. Valstybès žinios. 2003, Nr. 114-5115.

Lietuvos Respublikos valstybès tarnybos įstatymas. Valstybès žinios. 1999, Nr. 66-2130.

Lietuvos Respublikos viešojo administravimo istatymas. Valstybès žinios. 1999, Nr. 601945 ,

Lietuvos Respublikos darbo kodeksas. Valstybés žinios. 2002, Nr. 64-2569.

Lietuvos Respublikos socialinès apsaugos ir darbo ministro įsakymas „Dèl Darbo ginčų komisijos nuostatų, Darbo ginču komisijos darbo reglamento bei Atlygio mokejjimo darbuotojų ir darbdavių atstovams darbo ginčų komisijose ir kelionès išlaidų apmokèjimo tvarkos aprašo patvirtinimo“. Valstybès žinios. 2012, Nr. 143-7398.

Vilniaus miesto apylinkès teismo $2013 \mathrm{~m}$. birželio $10 \mathrm{~d}$. sprendimas civilinèje byloje Nr. 2-14099-803/2013.

Vilniaus miesto apylinkès teismo $2013 \mathrm{~m}$. liepos 5 d. sprendimas civilinèje byloje Nr. 2-20249-905/2013.

Vilniaus miesto apylinkès teismo $2013 \mathrm{~m}$. spalio $1 \mathrm{~d}$. nutartis, priimta civilineje byloje Nr. 2-36676-852/2013.

Vilniaus miesto apylinkès teismo $2013 \mathrm{~m}$. spalio 26 d. nutartis civilineje byloje Nr. 2-36843-582/2013. 
Anotacija. Straipsnyje aptariamas naujo individualiu darbo ginču nagrinejjimo modelio diegimas bei veikimas. $2013 \mathrm{~m}$. sausio 1 d. ivvykdyta reforma, kuria individualüs darbo gincaai pavesti spręsti specializuotoms kvaziteisminems institucijoms, sudaromoms prie Lietuvos Respublikos valstybines darbo inspekcijos prie Socialines apsaugos ir darbo ministerijos teritoriniu skyriu. Straipsnyje analizuojamas Lietuvos Respublikos darbo kodekso XIX skyriaus pakeitimo istatymas, isigaliojes $2013 \mathrm{~m}$. sausio 1 d., kuriuo remiantis nuo $2013 \mathrm{~m}$. sausio 1 d. formuojama darbo ginč komisiju bei Lietuvos teismu praktika darbo bylose, aptariamos aktualiausios problemos bei tolesnes ginču nagrinejimo perspektyvos.

Reikšminiai žodžiai: darbo teisé, individualus darbo ginčas, darbo santykiai, teisinis reguliavimas.

\title{
FEATURES OF FUNCTIONING OF THE NEW MODEL OF LABOUR DISPUTES IN LITHUANIA
}

\author{
Justinas Usonis, Asta Filimonenkova \\ Mykolas Romeris University, Lithuania
}

Summary. The new model of hearing of individual labour disputes and implementation of its operation in practice is discussed in the paper. After reform, which came into effect on January 1st, 2013, hearings of individual labour disputes have been delegated to the specialised quasi-judicial institutions, which are set up under the territorial divisions of the State Labour Inspectorate of the Republic of Lithuania. The article examines problems arising in practice after the changes of the Labour Code. The analysis is supported with practices of State Labour Inspectorate and the Courts of the Republic of Lithuania in employment cases since January 1st, 2013. The most relevant questions, such as competences of commissions of labour disputes, problems of process of appeal and further prospects, are discussed.

Keywords: labour law, individual labour disputes, labour relations, legal regulation.

Justinas Usonis, Mykolo Romerio universiteto Teisès fakulteto Verslo teisès katedros docentas. Mokslinių tyrimų kryptys: darbo teisè, ES darbo teisè.

Justinas Usonis, Mykolas Romeris University, Faculty of Law, Department of Business Law, Associated Professor. Research interests: employment law, EU labour law.

Asta Filimonenkova, Mykolo Romerio universiteto Teisès fakulteto Darbo teisès ir socialinio aprūpinimo programos magistrantė. Mokslinių tyrimų kryptys: darbo teisè, ES darbo teisè.

Asta Filimonenkova, Mykolas Romeris University, Faculty of Law, Master of Labour Law and Social Security Studies. Research interests: employment law, EU labour law. 